\section{A SYSTEM OF EPISTEMIC MODALITY IN THAI ${ }^{1}$}

\section{Suda Rangkupan ${ }^{2}$}

The paper explores the syntax and semantics of epistemic modality in Thai grammar. Four syntactic categories are found to express epistemic modality preverbal auxiliaries, initial particles, adverbs and final particles. Epistemic modality can also be further classified; five categories are found to be distinctive in the system of Thai grammar-assumptive, speculative, deductive, dubitative and certainty.

\section{Introduction}

Epistemic modality is a grammatical system that has drawn a lot of interest from linguists in various areas, both diachronic and synchronic (Palmer 1986; Bybee, Perkins and Pagliuca 1994; Swan and Westvik 1997; Nyuts 2001; van der Auwera and Dendale 2001; Johanson and Utas 2000) due to its complexity and its interdisciplinary nature, taking in syntax, semantics and pragmatics. Modality means the qualification of a statement in various aspects of the speaker's

\footnotetext{
${ }^{1}$ This research is funded by the Commission on Higher Education and the Thailand Research Fund. I would also like to thank Professor Dr. Pranee Kullavanijaya for her valuable comments and suggestions for this project and this paper in particular.

${ }^{2}$ Instructor, Linguistic Department, Faculty of Arts, Chulalongkom University, Bangkok
}

attitude. As an example, the sentence John should go home expresses an obligation that the speaker imposes on John to do the action go home. Traditionally, modality is the semantic category that is expressed by modal auxiliaries such as may, might and must in English. The term epistemic means 'knowledge'. Thus, epistemic modality can be understood in a simple way as 'modes of knowing' (Nuyts 2001). A rather comprehensive and explicit definition of epistemic modality given in Nuyts (2001: $21-22$ ) is as follows:

$$
\begin{aligned}
& \text { Epistemic modality is } \\
& \text { defined here as (the } \\
& \text { linguistic expression of) an } \\
& \text { evaluation of the chances } \\
& \text { that a certain hypothetical } \\
& \text { state of affairs under } \\
& \text { consideration (or some } \\
& \text { aspect of it) will occur, is } \\
& \text { occurring, or has occurred in } \\
& \text { a possible world which } \\
& \text { serves as the universe of } \\
& \text { interpretation for the } \\
& \text { evaluation process, and } \\
& \text { which, in the default case, is } \\
& \text { the real world ... }
\end{aligned}
$$

In Thai grammar books, the category of modality has not been so familiar as mood, which includes both sentence types such as interrogative, imperative and declarative, and other markers that express the speaker's attitude that is added to the content of the sentence (Upkitsilpasarn 1937,1968 and 
Phatranawig 1972). Most previous work has focused only on the syntactic properties of modal verbs (Panupong 1962, 1970, Shimpaiboon 1966, Kullavanijaya 1968, Dellinger 1975), but very little on their grammatical meaning (Bandhumedha 1982).

In his Thai reference grammar, Noss (1964) includes modals and modal verbs. Modals are defined as bound lexemes which occur between a subject and a predicate (1964: 133). Modal verbs are free lexemes but they occur in the same positions as modals and can only be differentiated from the latter by substituting for predicates. The grammatical category of modals is not identified. Rather, the meaning of each class is generalized. As an example, the meaning of mak4 Class is 'likelihood, the imminence of action and frequency of action'. Similarly, Sindhvananda (1970), Dellinger (1975) and Sriphen (1982) propose a classification of modal auxiliaries mainly based on their syntactic properties but do not provide any semantic analysis of these modals.

We can see that most previous work focuses on modals or modal auxiliaries. In fact, as noted in Palmer (1986: 2), modality, including epistemic modality, can be expressed by devices other than verbs. Nuyts (2001: 29) has also argued that there are other linguistic forms, including modal adverbs, e.g. probably, predicatively used modal adjectives, e.g. it is probable that..., and mental state predicates, e.g. I think that ...Thus, this paper does not limit the scope of the study only to the modal auxiliary; rather, it explores various types of grammatical forms that express epistemic modality in Thai from the semantic aspect, using the actual corpus of data and then describes their structural properties.
The major purpose of this paper is to discover the system of marking epistemic modality in Thai. Therefore, besides their syntactic properties, the semantic classification of the epistemic markers needs to be investigated. Yet until now there has not been much agreement on how epistemic modality should be further classified. Lyons (1977) distinguishes objective and subjective epistemic modality. There are two major types in Palmer (1986) - evidentials and judgments, which can be further divided. Bybee et al (1994) use three main types in their typological study-possibility, probability, and inferred certainty. Vet (1998) proposed to go back to Wittenstein's distinction between monstration and veridiction in his analysis of modal expressions in French. An interesting approach is the proposal by Nuyts (1992) who also takes into account the interaction between epistemic and evidential marking. In Thai, as shown in the actual corpus, epistemic markers tend to co-occur. Thus, this paper does not only describe the meaning of each epistemic marker but also examines the interaction among various types of epistemic modality.

\section{Syntactic properties}

The first point one needs to investigate in studying Thai grammar is to identify grammatical forms in the grammatical system. We, thus, set out by proposing criteria for identifying epistemic markers in Thai sentences before syntactic properties of the identified grammatical words are described.

\subsection{Identifying epistemic markers in simple sentences}

This study proposes using a sentence frame for testing the epistemic meaning of the 
sentence. First, we identify sentences in the corpus that have an epistemic reading. Epistemic modality as defined by Lyons 1977, Palmer 1986 and Nuyts 2001 is:

1) the assessment of the chance that something has occurred, is occurring or will occur

2) the a ssessment is performed by the speaker of the sentence

As an example, sentence (1a) has an epistemic reading while ( $1 \mathrm{~b})$ does not.

a. Jit khoy' $\mathrm{klap}^{2}$ baan $^{3}$
Jit may return home
lecw $^{4}$
already

'Jit must have gone back home.'

b. Jit klap $^{2} \quad$ baan $^{3} 1 \varepsilon \varepsilon w^{4}$ Jit return home already 'Jit went back home.'

Compare the two sentences above. We can see that in sentence (1a) the speaker asserts that it is very likely that Jit went back home whereas sentence ( $1 b$ ) does not give such a reading. Rather, the event in (1b) is presented as having actually occurred. The formal difference between the two sentences is that sentence (1a) has the word $k h o \eta^{I}$ while (1b) does not. Thus, $k h o \eta^{I}$ is an element that is highly likely to be epistemic marker.

Next, we confirm the epistemic interpretation by using a paraphrase. A complex sentence with the verb 'speculate' in the main clause is proposed as a frame, as given in (2). A paraphrase sentence is constructed by embedding a clause that omits the element in question in the sentence frame, as illustrated in (3).
(2) chan $^{5} \quad$ khaat $^{3}$ kha $^{4}$ nee ${ }^{1}$ waa $^{3}$ I speculate CMPL 'I speculate that ...'

(3) chan $^{5} \quad$ khaat $^{3} \mathrm{kha}^{4}$ nee $^{1}$ waa $^{3}$ I speculate CMPL Jit $\mathrm{klap}^{2} \quad$ baan $^{3} \quad \mathrm{l} \varepsilon \mathrm{w}^{4}$ Jit return home already 'I speculate that Jit has gone back home.'

Then, when sentence (3) is compared with (1), we find that the two sentences have the same meaning so the epistemic reading of sentence (1) is confirmed. Therefore we conclude that $k h o \eta^{\prime}$ is an epistemic marker.

\subsection{Syntactic classes of epistemic markers}

Based on the corpus of actual data, this study has found 19 epistemic markers which can be grouped into four classes with respect to their lexical and distributional properties: preverbal auxiliary, initial particle, adverb, and final particle.

\subsubsection{Preverbal auxiliaries}

Modality is typically expressed by auxiliaries. In Thai there are three preverbal auxiliaries whose basic function is to express epistemic modality: $2 a a t^{2}$ 'may' khoy ' 'might' and yom 'must'. An important property of a Thai auxiliary is that it occurs in only one position, i.e. in front of the verb in this case, as shown in (4). Sentences (5) and (6) show that khon' cannot occur in other positions, either sentence-initially or post-verbally, respectively.

(4) Jit khoy ${ }^{1} \operatorname{kin}^{1}$ khaaw $^{3}$ yuu $^{2}$ Jit might eat rice CONT

'Jiit might be eating now.' 
(5)

${ }^{*} \mathbf{k h o y}^{1}$ Jit kin $^{1}$ khaaw $^{3}$ yuu $^{2}$ might Jit eat rice CONT

$\begin{array}{ccccc}(6)^{*} \text { Jit } & \text { kin }^{1} & \text { khoy }^{1} & \text { khaaw }^{3} & \text { yuu }^{2} \\ \text { Jit } & \text { eat } & \text { might } & \text { rice } & \text { CONT }\end{array}$

\subsubsection{Initial particle}

Epistemic modality can also be expressed by particles that occur in the initial area of a sentence so they are broadly called initial particles. They can basically occur in front of the subject, as in (7), or between the subject and the main verb, as in (8), but not postverbally, as in (9). To illustrate,

(7) thaa thaag $^{1}$ Jit yaak ${ }^{2}$ yuu $^{2}$ baan $^{3}$ gesture Jit want stay home 'It seems that Jit wants to stay home.'

(8) Jit thaa ${ }^{3}$ thaag $^{1}$ yaak $^{2}$ yuu $^{2}$ baan $^{3}$ Jit gesture want stay home

'It seems that Jit wants to stay home.'

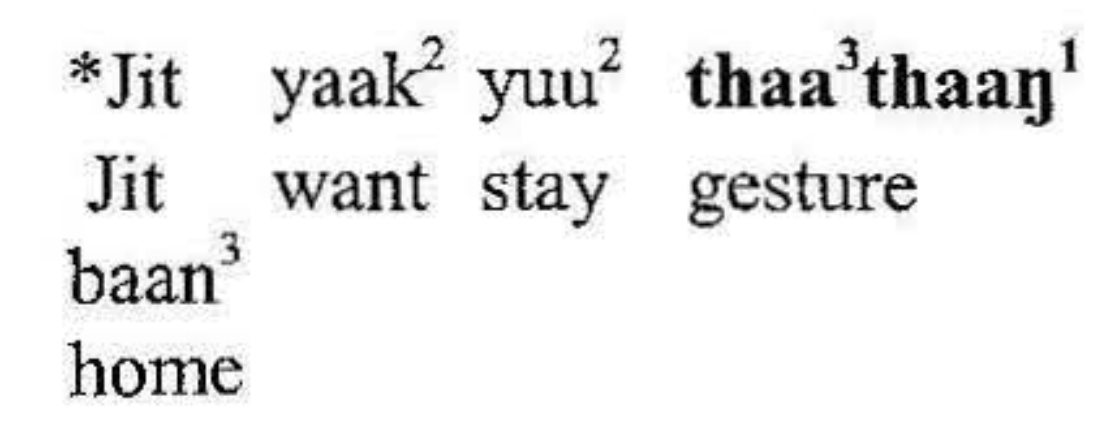

However, we also find that the initial epistemic particle can occur at the end of the sentence but it needs to be after a final particle as shown in (10).

$$
\begin{array}{llll}
\text { a. } & \text { Jit } & \text { yaak }^{2} \quad \text { yuu }^{2} & \text { baan }^{3} \\
\text { Jit } & \text { want stay } & \text { home } \\
\text { na? } & \text { thaa thaa }^{3} & \\
\text { FP } & \text { gesture }
\end{array}
$$

'Jit wants to stay home, judging from how he appears.'

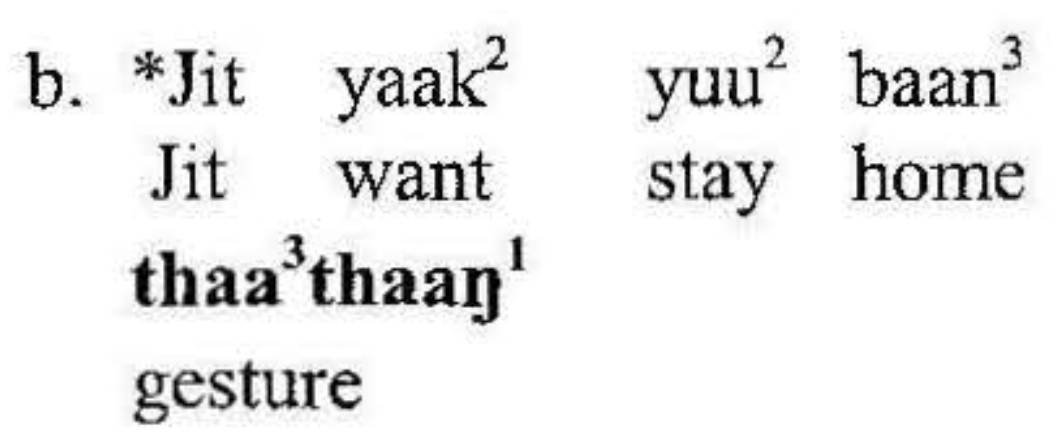

Considering their lexical properties, we find that initial particles are derived from nouns or predicates, such as tha $a^{3}$ 'gesture' and $d u u^{l}$ thaa ${ }^{3}$ thaay $^{l}$ 'see gesture'. Their syntactic behaviors raise quite a few grammatical problems in Thai. This study considers them to be grammatical particles, rather than lexical nouns or a clause because they are closed class forms. They all have the meaning of ' gesture ${ }^{13}$. In fact, $t h a a^{3}$ indicates a very wide range of evidential meaning, gestures, other nonverbal expressions and even reasons in the inferential process. This is a characteristic of grammatical words. Other nouns of nonverbal expressions, such as voice or eyes, can occur immediately before the subject but not in any other position.

\subsubsection{Adverbs}

Epistemic meaning can also be expressed by using certain kinds of adverbs. Adverbs of this type are included since they are closed class forms although their morphological forms vary the most among the four classes. There are two positions in which these adverbs can occur - sentenceinitial and clause-final - but each may occur only in one fixed position. Sentenceinitial adverbs include baan' thii ' 'maybe', son'say ${ }^{5}$ 'maybe', and naa klua' 'doubt'. Examples of clause-final adverbs are $n \varepsilon \varepsilon^{3}$

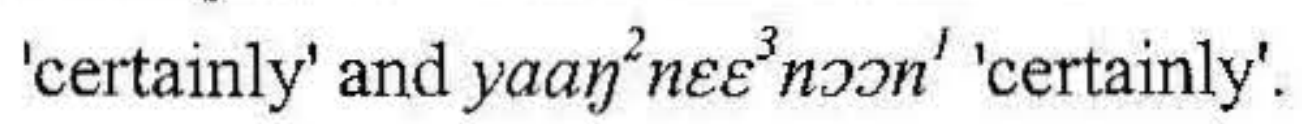

\section{(11) $\operatorname{soy}^{5}$ say $^{5} \quad$ khaw $^{5}$ may $^{3}$ pho tcay ${ }^{1}$ suspect 3sg NEG satisfied 'Maybe he is not satisfied.'}

\footnotetext{
${ }^{3}$ An extensive list of gesture nouns that are found to indicate inferential stance in a sentence of emotion or private state predicates (Rangkupan 2001).
} 
(12) Jit pen ${ }^{1} \operatorname{soot}^{2} \quad n \varepsilon \varepsilon^{3}-n \varepsilon \varepsilon^{3}$ Jit be single certain-RED 'Jit is definitely single.'

\subsubsection{Final particles}

Final particles are markers that occur at the end of the sentence and cannot occur in other positions. Only one final particle is found to mark epistemic modality in the corpus, i.e. $m a \eta^{4}$.

\section{(13) Jit $\mathrm{klap}^{2} \quad \mathrm{baan}^{3} 1 \varepsilon \varepsilon \mathrm{w}^{4} \mathbf{m a \eta}^{4}$} Jit return home already FP

'Jit already went back home, maybe.'

$$
\begin{aligned}
& \text { (14) * may }{ }^{4} \text { Jit } \quad \text { klap }^{2} \quad \text { baan }^{3} 1 \varepsilon \varepsilon w^{4} \\
& \text { FP Jit return home already } \\
& \begin{array}{ccc}
(15){ }^{*} \text { Jit } \mathbf{m a y}^{4} & \text { klap }^{2} & \text { baan }^{3} 1 \varepsilon \varepsilon w^{4} \\
\text { Jit FP } & \text { return } & \text { home already }
\end{array}
\end{aligned}
$$

In sum, epistemic modality is expressed in Thai grammar by four types of closed-class forms-preverbal auxiliaries, initial particles, adverbs and final particles. Preverbal auxiliaries and final particles can occur in only one position whereas initial particles and adverbs can occur in many positions. Furthermore, epistemic markers in the latter two classes vary a lot in terms of their morphological forms. Some are derived from nouns or verbs and the others allow a modification by some degree adverbs. This might suggest that these items are in the process of being grammaticalized.

\section{Semantic analysis}

Previous studies on epistemic modality, including modality in general, have proposed many ways to distinguish major subclasses of epistemic modality. Lyons (1977) has distinguished between objective and subjective e pistemic modality. Palmer (1986) has found in his typological study two main systems - evidentials and judgments. Judgments can be further divided into inference and confidence. Bybee et al (1994) consider three major subclasses of epistemic modalitypossibility, probability and inferred certainty.

This study attempts to distinguish major types of epistemic meaning as shown in Thai sentences, based on the actual corpus of data. The result of the semantic classification should reveal the system of Thai epistemic marking. This section, thus, first reviews the three proposals mentioned above. Then, the semantic analysis of Thai epistemic markers is provided. Finally, the categorization of epistemic marking considered from Thai findings is proposed.

Palmer (1986) differentiates four ways of epistemic qualification:

There are at least four ways in which a speaker may indicate that he is not presenting what he is saying as a fact, but rather:

(i) that he is speculating about it (speculative)

(ii) that he is presenting it as a deduction (deductive)

(iii) that he has been told about it (quotative)

(iv) that it is a matter only of appearance, based on the evidence of (possibly fallible) senses (indirect evidence)

(Palmer 1986: 51)

According to Palmer, all four types are concerned with the speaker's "commitment to the truth of the proposition being expressed" (Palmer 1986: 51). 
In their typological study on modality, Bybee et al (1994) include possibility, probability and inferred certainty as subclasses of epistemic modality. Indirect evidentials are also considered as having an epistemic value. Possibility indicates a lesser likelihood for a proposition to be true than probability, while inferred certainty shows that the speaker has good reason to believe that the proposition is true. Indirect evidential expresses the speaker's indirect knowledge regarding the truth of the proposition. (Bybee et al 1994: 180-1)

\subsection{Speculative, Deductive and Assumptive}

It is found that preverbal auxiliaries ?aat ${ }^{2}$ 'may', khon' 'might' and yom 3 'must' can be clearly distinguished. The data in (16) show the semantic differences between ?aat ' 'may' and $k h o \eta^{\prime}$ 'might'. The meaning of yom 3 'must' is illustrated in (17). Note that due to the length of the data, examples (16) and (17) are presented in the form of Thai orthography. The auxiliary in question is put in brackets before the predicate in each clause.

$$
\text { (a) ฟักเร่งเดินเร็วขึ้น (b) นึกเป็นห่วงนางที่อยู่ย้าน }
$$

คนเดียวในกระต๊อบ $(\mathrm{c})$ เวลานี้จวนมืดแล้ว $(\mathrm{d})$ นางคงหิว

(e) นางอาจจะเดินตามหา (f) นางอาจจะสุมไฟไล่ยุงใน กระต๊อบแล้วลื้มดู

(a) Fak hurried along. (b) He felt concerned about M'am, who was alone in the hut. (c) It was getting dark, (d) she [khon $\left.{ }^{1}\right]$ was probably hungry (e) and [?aat $\left.{ }^{2}\right]$ may even have gone out looking for him. (f) Maybe she [?aat $\left.{ }^{2}\right]$ had lit a fire in the hut to drive away the mosquitoes and then forgotten about it. ${ }^{4}$

The above data clearly show the semantic difference between $k h^{\prime} \eta^{\prime}$ and Pat $^{2}$. The fact that it is late in the evening, as shown in (c), has led the speaker to conclude that the participant M'am is hungry. In the next two clauses, (e) and (f), M'am's possible actions of going out in (e) and lighting a fire in ( $f$ ) a re s peculated a s likely to have happened. They are just some among many other possible actions.

The semantic distinction between $2 a a t^{2}$ 'may' and khon' 'might' can be viewed as the distinction between speculative and deductive, on the one hand, and possibility and probability on the other. However, it seems to be less clear to differentiate them as objective vs. subjective, as proposed by Lyons (1977) because they both have the $I$ say-so component. None of the three marked actions are objective facts. Rather, they are all based on the evaluator's beliefs about M'am's pattern of behavior.

Another preverbal auxiliary that marks epistemic modality is yom 3 'must'. Its meaning can be illustrated as follows:

(17) (a) อายุและสุขภาพของผู้ใช้ยาก์สำคัญ (b) คนแก่ หรือคนที่มีหลายโรคย่อมมีโอกาสเกิดผลจากปฏิกิริยาระหว่างยา มากกว่าคนหนุ่มสาว หรือคนที่แข็งแรง

'(a) Age and the user's health are also significant. (b) Elders or those who have a lot of health problems customarily $\left[\mathrm{ysm}^{3}\right]$ are more vulnerable to the effects of drug interaction than youngsters or healthy people.'

\footnotetext{
4 The translation is cited from the novel translated into English by Phongdeit Jiangphatthana-kit and Marcel Barang.
} 
The proposition of sentence $(17 \mathrm{~b})$ is presented as necessarily true resulting from a commonly shared belief that elders and ill people are at higher risk of health problems. Therefore, $y \mathrm{sm}^{3}$ marks a deduction from a set of standard beliefs, assumed by the evaluator to be commonly shared. Following Palmer (1986), this type of epistemic modality is called assumptive.

\subsection{Evidentials}

The type of evidential that is found in Thai is indirect evidential, or inferential evidential, marked by initial particles. It indicates that the proposition is believed by the evaluator to be true, based on some observable evidence, i.e. image, sound, smell, taste and feel. An example is shown below. N ote that only the sentence that is epistemically marked is transcribed; its relevant context is only translated and put in square brackets.

\section{(18) khruu $^{1}$ yai $^{4} \quad$ thaa $^{3}$ thaay $^{1}$ tok $^{2} \mathrm{jai}^{1}$ principal gesture be surprised}

'The Principal looked surprised. [He yelled out as if he didn't believe what he had just heard.]'

Emotion is a private state; the only person who knows the truth of the experience is the experiencer of the emotion. In (18) the speaker talked about another person's private state. In the situation, it is observed that the Principal cried out loudly. Based on the observation of the Principal's gesture and other expressions, the speaker concluded that the subject, the Principal, was surprised. This type of marking is considered indirect evidential. This is an inferential process since the speaker does not really know the truth about the Master's emotional state but he infers from his loud cry that he is surprised.
Indirect evidentials can also be expressed by the preverbal auxiliary $k h o \eta^{\prime}$. To illustrate,

$$
\begin{aligned}
& \text { luuk }^{3} \mathrm{me \varepsilon w}^{1} \mathrm{ko}^{3} \quad \mathbf{k h o y}^{1} \mathrm{~d}^{2} \mathrm{n}^{1} \text { pay } \\
& \text { kitty then might walk go } \\
& 1 \varepsilon \varepsilon \mathrm{w}^{4} \mathrm{phlat}^{4} \text { tok }{ }^{2} \log ^{1} \\
& \text { then incidentalfall down } \\
& \text { pay }^{1} \\
& \text { go }
\end{aligned}
$$

'[They didn't close the drain.] The kitty might have walked over it and fallen in.'

In (19) considering the fact that the drain was not closed, the speaker deduces that the event of the kitty walking and falling down into the drain has occurred. The proposition is presented as a deduction.

\subsection{Certainty vs. Dubitative}

Certainty, also called confidence (Palmer 1986), refers to the degree of certainty the speaker has towards the truth of the proposition. It is found that Thai has two degrees of certainty-high and low, expressed by adverbs. Thai also has another similar category, the so-called dubitative ${ }^{5}$, which indicates that the speaker doubts the truth value of the proposition that is assessed by the other person. To illustrate,

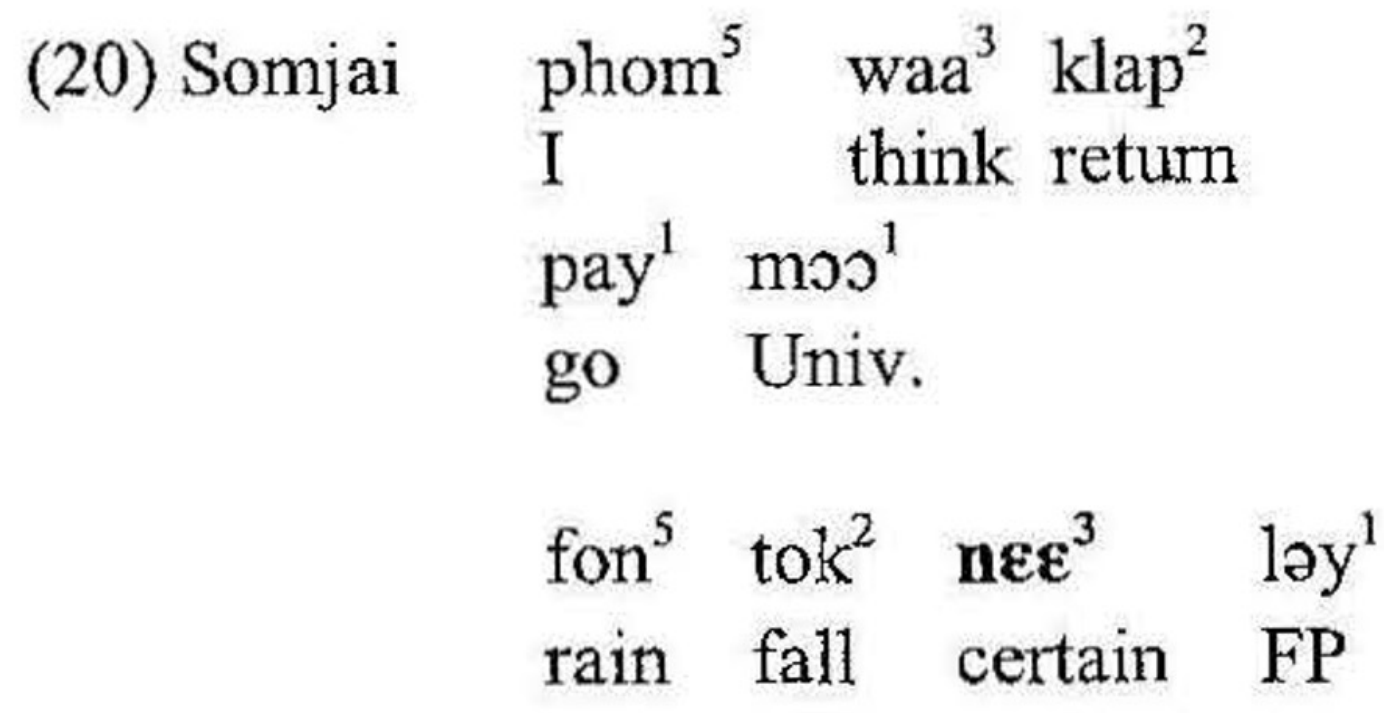

\footnotetext{
${ }^{5}$ The term "dubitative" follows Nida (1949)
} 


$\begin{array}{lll}\text { Chaiyaa } & \text { chuay }^{3} & \text { nii }^{4} \quad \text { rəa }^{5} \\ \text { time } & \text { this } Q \\ & \text { yay } & \text { may }^{4} \\ \text { not yet } & \mathrm{FP}\end{array}$

Somjai I think when I get back to the campus, it will surely be raining.

Chaiyaa This time of the year? Not yet I don't think.

The conversational data in (20) illustrate two types of epistemic marking. Somjai expresses her belief about the rain situation with a high degree of certainty, using the adverb $n \varepsilon \varepsilon^{3}$ while her conversational partner, Chaiyaa, who does not agree with her, expresses his doubt in Somjai's belief, using the final particle $m a \eta^{4}$ and in turn, evaluates the truth of the proposition to be otherwise.

The dubitative particle has various phonetic forms, as also noted in Bhamoraput (1972), such a s $k r a^{l} m a \eta^{l}, k a^{l} m a \eta^{I}, l a^{l} m a \eta^{l}, m a \eta^{\prime}$ and $m a \eta^{4}$. Adverbs of high certainty include $n \varepsilon \varepsilon^{3}$ 'certainly' and those expressions that contain the word $n \varepsilon \varepsilon^{3}$ such as $n \varepsilon \varepsilon^{3} n \varepsilon \varepsilon^{3}$ 'certainly' and $n \varepsilon \varepsilon^{3} n \supset n^{l}$ 'certainly'. Adverbs of low certainty include baan'thii ${ }^{I}$ 'perhaps' and $k^{3}$ pen $^{l} d a i^{3}$ 'possibly'. Dubitative is marked by the final particle $\mathrm{ma \eta}^{4}$.

To summarize, in terms of semantics, epistemic modality is divided into six subcategories - speculative, deductive, assumptive, evidential, dubitative, low certainty and high certainty.

\section{Subcategorization of epistemic modality}

In the previous section we have shown a semantic analysis of epistemic markers primarily based on the definitions used by Palmer (1986) and Bybee et al (1994). In fact, the analysis is merely a semantic interpretation of Thai epistemic markers. This paper argues that in order to find the system of marking epistemic modality in Thai, we need to look for the constraint that underlies the marking system. As suggested in a lot of previous work, co-occurrence plays an important role in Thai grammar (Panupong 1962, 1970; Kullavanijaya 1968). Epistemic markers, in particular, are restricted in terms of their co-occurrence with each other. Thus, this section presents patterns of co-occurrence and discusses their restrictions. Finally, the semantic categories that make up the system of epistemic modality in Thai are proposed.

\subsection{Combination of epistemic meaning}

In Thai epistemic markers may occur in many patterns of combination. Since the data tend to be quite long due to being drawn from the actual corpus, we will first show examples of some combinations before we present the findings of all patterns of co-occurrence.

Examples of combinations of epistemic markers are as follows:

\section{Speculative and Low Certainty}

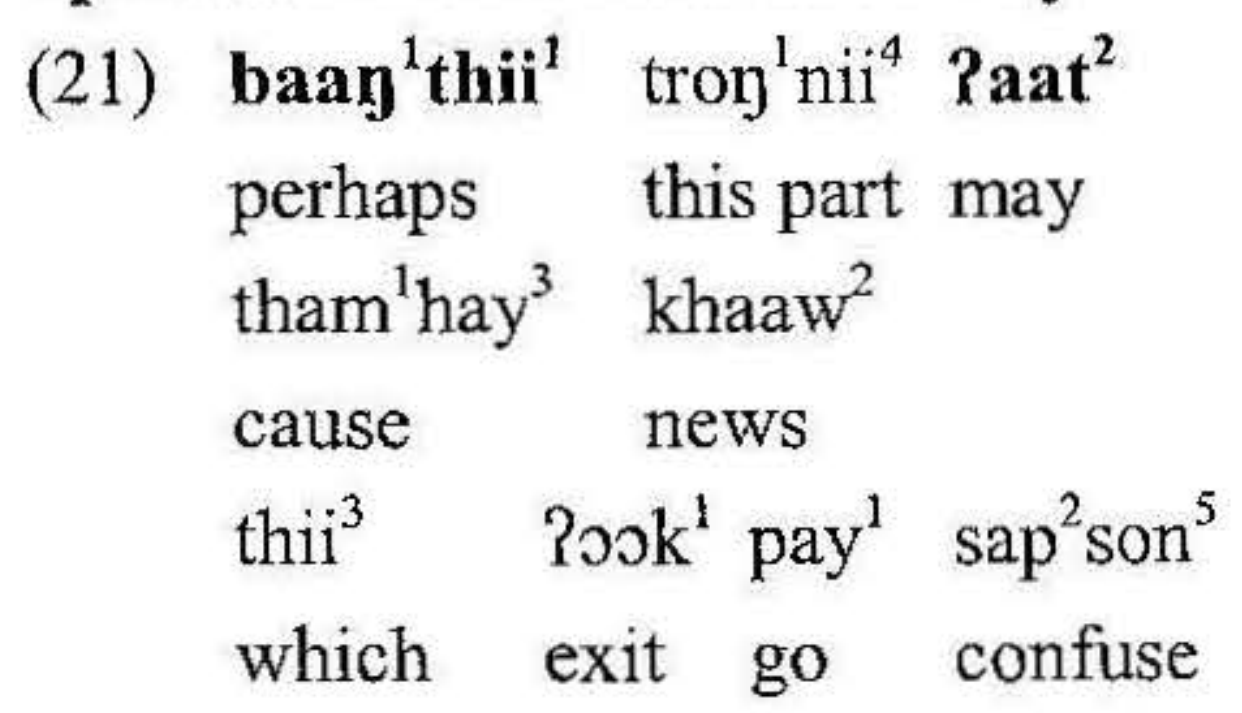


'Perhaps this may have caused the news that came out to be confusing.'

Sentence (21) shows the combination of the speculative marker ?aat ${ }^{2}$ and an adverb of low certainty baay $^{I}$ thii ${ }^{I}$. In the corpus Pat $^{2}$ has not been found to co-occur with any markers of high certainty. If we use the speculative modal with the adverb of high degree of certainty, the sentence is considered unacceptable, as shown in (22).

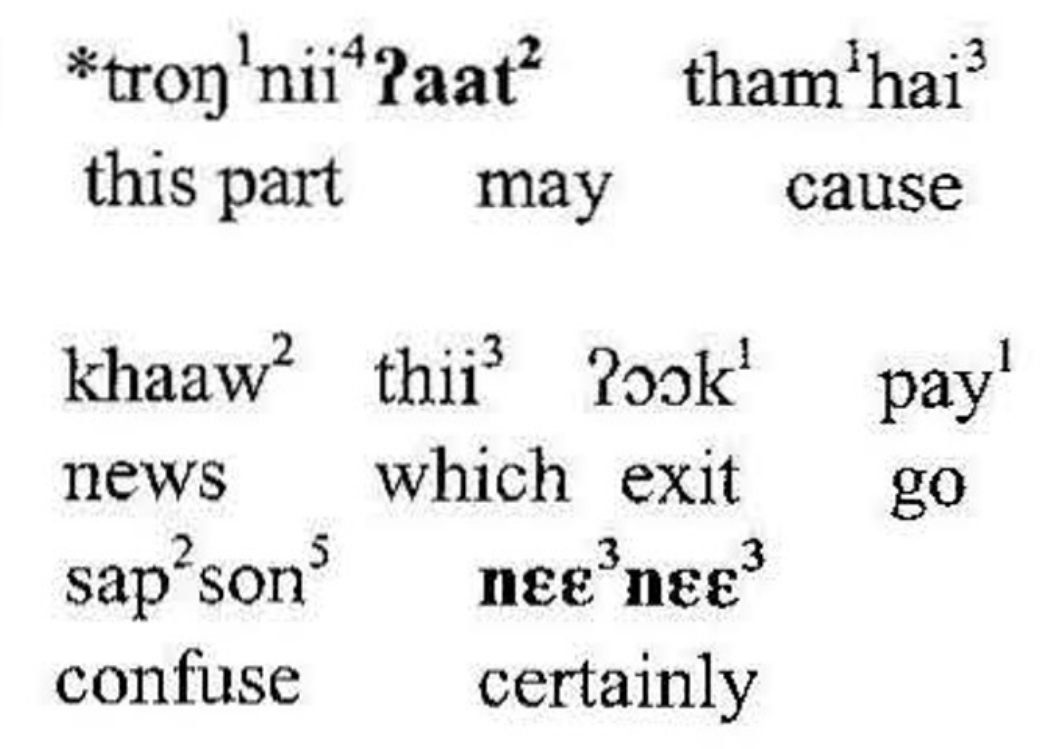

\section{Deductive and Dubitative or High Certainly}

It is found that the deductive marker $k h o \eta^{l}$ can co-occur with either dubitative or high degree of certainty as shown in (23) and (24) below respectively.

\section{(23) Fak $\operatorname{man}^{1}$ khoy $^{1}$ may $^{3}$ kroot $^{2}$ \\ Fak 3sg might NEG angry $\operatorname{man}^{4}$ \\ FP

$\begin{array}{lll}\text { riag }^{3} & \mathrm{khe \varepsilon}^{3} \mathrm{nii}^{4} & \text { Re }{ }^{1} \\ \text { matter } & \text { just this } & \text { only }\end{array}$

'Fak might not be angry; it's just a little thing.'

(24) man $^{1}$ khog $^{1}$ may $^{3}$ kiaw $^{2}$ kap $^{2}$ it might NEG be about

\author{
rook $^{3} \operatorname{sim}^{1} \operatorname{saw}^{3} \mathbf{n} \boldsymbol{\varepsilon \varepsilon ^ { 3 }}$ \\ depression certainly
}

'It shouldn't be relevant to the depression.'

In sentence (23) the speaker does not know whether the subject Fak is angry but he reasons that Fak is not. He also expresses his commitment to the truth of the proposition at the low level of certainty. We can say that the epistemic modal $\mathrm{kho \eta}^{l}$ is neutral in terms of the epistemic degree since it is harmonic with an element of any degree of certainty.

\section{Evidential and High Certainty}

The following example illustrates the combination of the initial particle $s o \eta^{5} s a i^{5}$ indicating evidential and the adverb of high certainty $n \varepsilon \varepsilon^{3}$. The combined meaning results in the higher degree of certainty.

(25) sog $^{5}$ sai $^{5}$ khiin ${ }^{1} \mathrm{nii}^{4} \mathrm{ko}^{3} \quad \mathrm{dai}^{3}$ suspect tonight then get duu ${ }^{1}$ Saket Khaaw see Saket Khaaw

$\begin{array}{lll}\mathbf{n e q}^{3} & \text { ləy }^{1} & \text { nia }^{3} \\ \text { certainly } & \text { FP } & \text { FP }\end{array}$

'I think tonight we could make it to the Saket Khaaw Show definitely.'

The above data illustrate the use of epistemic markers in combination. But not all epistemic markers can co-occur with each other. We have found that there are restrictions on co-occurrence as shown in Table 1. 


\begin{tabular}{|c|c|c|c|c|c|c|c|}
\hline & Assumptive & Speculative & Deductive & Evidential & Dubitative & $\begin{array}{c}\text { Low } \\
\text { Certainty }\end{array}$ & $\begin{array}{c}\text { High } \\
\text { Certainty }\end{array}$ \\
\hline Assumptive & $x$ & $x$ & $x$ & $x$ & $x$ & $x$ & $\checkmark$ \\
\hline Speculative & $x$ & $x$ & $x$ & $x$ & $\checkmark$ & $\checkmark$ & $x$ \\
\hline Deductive & $x$ & $x$ & $x$ & $\checkmark$ & $\checkmark$ & $x$ & $\checkmark$ \\
\hline Evidential & $x$ & $x$ & $\checkmark$ & $x$ & $\checkmark$ & $x$ & $\checkmark$ \\
\hline \begin{tabular}{c} 
Dubitative \\
\hline $\begin{array}{c}\text { Low } \\
\text { Certainty }\end{array}$
\end{tabular} & $x$ & $\checkmark$ & $\checkmark$ & $\checkmark$ & $x$ & $x$ & $x$ \\
\hline $\begin{array}{c}\text { High } \\
\text { Certainty }\end{array}$ & $\checkmark$ & $x$ & $\checkmark$ & $\checkmark$ & $x$ & $x$ & $x$ \\
\hline
\end{tabular}

Table 1 Co-occurrence properties of epistemic markers

From Table 1 we can see that assumptive can only combine with a marker of high certainty while speculative can only occur with dubitative and low certainty. Deductive markers co-occur with evidential, dubitative and certainty. None of the three categories marked by modal auxiliaries co-occur with each other. Evidential shares the same pattern of co-occurrence with deductive. Low certainty is the only type that can be doubled.

Several points can be made from the cooccurrence patterns of epistemic markers. First, the three types of epistemic modality marked by preverbal auxiliaries are clearly distinct from each other since they have totally different patterns of co-occurrence: assumptive with high certainty, deductive with dubitative or high certainty, and speculative with dubitative or low certainly.

Secondly, evidential has the same pattern as deductive, i.e., co-occurrence with dubitative or high certainty. It is not surprising to put evidential in the category of deductive since it involves a kind of judgment as well, as noted in Palmer (1986: 69). The only difference is that evidential requires some reference to evidence as a basis for judgment in the context while deductive is implicit in this respect.

Third, dubitative, low certainty and high certainty all involve the speaker's strength of commitment to the truth of the proposition. One might think of lumping all three into one category of certainty. However, it is found that they are distinctly different in terms of how they interact with other epistemic markers.

Low certainty can only co-occur with a speculative marker, as shown in (21). The result of the combination is harmonic and considered simply a single modality, i.e. speculation or evaluating the possibility. This phenomenon is also found in English. According to Lyons (1977), may and possibly in a sentence such as He may possibly have forgotten express the same degree of modality. Thus, the combination is considered the double realization of a single modality such that the modal elements "reinforce each other" in terms of 
the epistemic qualification (Lyons 1977: 807). Therefore, low certainty, whose occurrence is restricted to speculative in Thai, should be incorporated into the category of speculative.

Dubitative is a category that also indicates the speaker's commitment to the truth of the proposition. However, the reading of its degree seems to vary when it is combined with other epistemic markers. That is, when combined with the speculative, it increases somewhat the degree of certainty. But when it combines with a deductive, it tones down the speaker's certainty, as seen in (23).

High certainty can occur with assumptive or deductive markers. It is expressed by adverbs. This may lead us not to consider this category as part of the epistemic system since they might simply be a modification of certainty or confidence, rather than an assessment of the truth of the proposition. However, evidence that these adverbs express epistemic modality can be found when they co-occur with deontic modals since they serve to evoke the epistemic value that is subsided in these deontic modals. To illustrate,

$$
\begin{aligned}
& \mathrm{kuu}^{1} \text { tog }^{3} \text { yuu }^{2} \text { nai }{ }^{1} \text { kron }^{1} \\
& 1 \mathrm{sg} \text { must be in cage } \\
& \text { saam }^{5} \quad \text { dian }^{1} \\
& \text { three month } \\
& \text { taai }^{1} \ldots \text { kuu }^{1} \text { ton }^{3} \text { taay }^{1} \\
& \text { die... } 1 \text { sg must die } \\
& n \varepsilon \varepsilon^{3} \\
& \text { certainly }
\end{aligned}
$$

'I must be in prison for three months. Die! I'll certainly die.' ${ }^{6}$

In (26), the preverbal auxiliary $t \supset \eta^{3}$ 'must' in the last clause is also used epistemically to

\footnotetext{
${ }^{6}$ The dotted markers follow the original text.
}

indicate a very strong degree of commitment on the part of the speaker to the probability of the event. Note that the data in (26) also

\begin{tabular}{|c|c|c|}
\hline naa $^{3}$ tca? & $\operatorname{pra}^{2}$ maan ${ }^{1}$ & tçet ${ }^{2}$ khuap \\
\hline $\begin{array}{l}\text { should } \\
\operatorname{man}^{4}\end{array}$ & $\begin{array}{l}\text { be around } \\
\operatorname{rap}^{4}\end{array}$ & seven year \\
\hline FP & & \\
\hline
\end{tabular}
show the comparison between the deontic use (in the first clause) and the epistemic use of $t \partial \eta^{3}$ in the nearby context.

Note that the final particle marking the dubitative $m a \eta^{4}$ has the same function as adverbs of high certainty, as shown below.

\section{(27)Poo Khai:}

[Nuu Maem: Right. At the time of meeting how old were you?]

Poo Khai I must have been around seven years old, I guess.

In sentence (27) the final particle of low certainty $\mathrm{man}^{4}$ co-occurs with the preverbal auxiliary naa ${ }^{3} t 6 a ?^{2}$ 'must', whose basic category is deontic. The sentence is interpreted as an assessment of the age of the speaker when he himself was very young. The s peaker expresses the truth of the proposition as an approximation with some confidence. The preverb naa ${ }^{3} t_{6} a ?^{2}$ 'must' here is epistemically used.

The ambivalent nature of the modals has been noted by many linguists such as Palmer (1986) and Sweetser (1990). Although in most cases Thai deontic modals express obligation, we find some sentences that could be ambiguous in terms of the speaker's involvement with the proposition. Combining these modals with markers of certainty can bring out the epistemic value and eliminate ambiguity. 
We may conclude that there are five categories in the marking system of epistemic modality in Thai:

1) Speculative

a. possibility

b. can be marked by a preverbal auxiliary ?aat ${ }^{2}$ or adverbs of low certainty

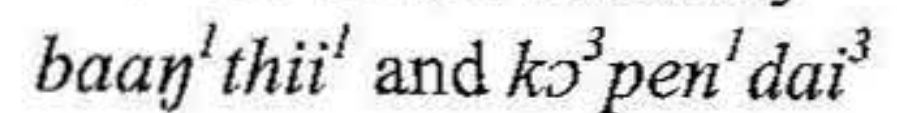

c. low certainty can be reinforced by multiple uses of adverbs, strengthening the degree of objectivity

d. the source or basis for the evaluation need not be present in the context

2) Assumptive

a. concluded from presumably known facts

$b$. is marked by a preverbal auxiliary y $m 3$ and can be combined with adverbs of high certainty $n \varepsilon \varepsilon^{3}$

c. the basis for the evaluation is generalized and emphasized, showing intersubjectivity

3) Deductive

a. two types-probability and inferential evidence

b. is marked by a preverbal auxiliary $\mathrm{kho \eta}^{\prime}$

c. evidential is marked by $k h o \eta^{I}$ and initial particles

d. markers of both types can be combined to reinforce deductive strength and seem to show high subjectivity

e. the basis for the evaluation tends to be specified as evidence indirectly observed by the evaluator, viz the speaker, yielding the subjectivity

4) Dubitative

a. an evaluation of probability yet showing uncertainty

b. is marked by the final particle $m a \eta^{4}$

c. when combined with speculation it increases the degree of certainty, but with deductive, it lessens the speaker's certainty.

d. has a dual function of marking both epistemic modality and pragmatic interaction, thus is a grammatical and interactional particle

5) Certainty
a. an evaluation of probability with high certainty, varying in degree
b. is marked by adverbs of certainty
c. evokes the epistemic value when used with deontic modals

\section{Concluding remarks}

This paper attempts to determine the system of epistemic marking in Thai. It is mainly based on the actual corpus of data, both written and spoken. The epistemic markers identified in the study belong to various syntactic categories. A complicated analysis seems to be the identification of their semantic subcategories of epistemic modality. Some markers have more than one meaning. Also, these semantic 
categories are closely related by nature. In Thai, in particular, markers occur in combination. Thus, the study examines the co-occurrence patterns and restrictions of these markers. The findings are used as a basis for distinguishing semantic subcategories of epistemic modality that form the system of marking epistemic modality in Thai.

However, there remain other problems concerning epistemic modality in Thai, especially in the domain of discourse and pragmatics. It is observed that some markers are used as discourse strategies, such as for politeness and closing a conversation. The following example shows the redundant use of speculative markers to show politeness in the context of talking about a sensitive topic and referring to an organization that has high social power.

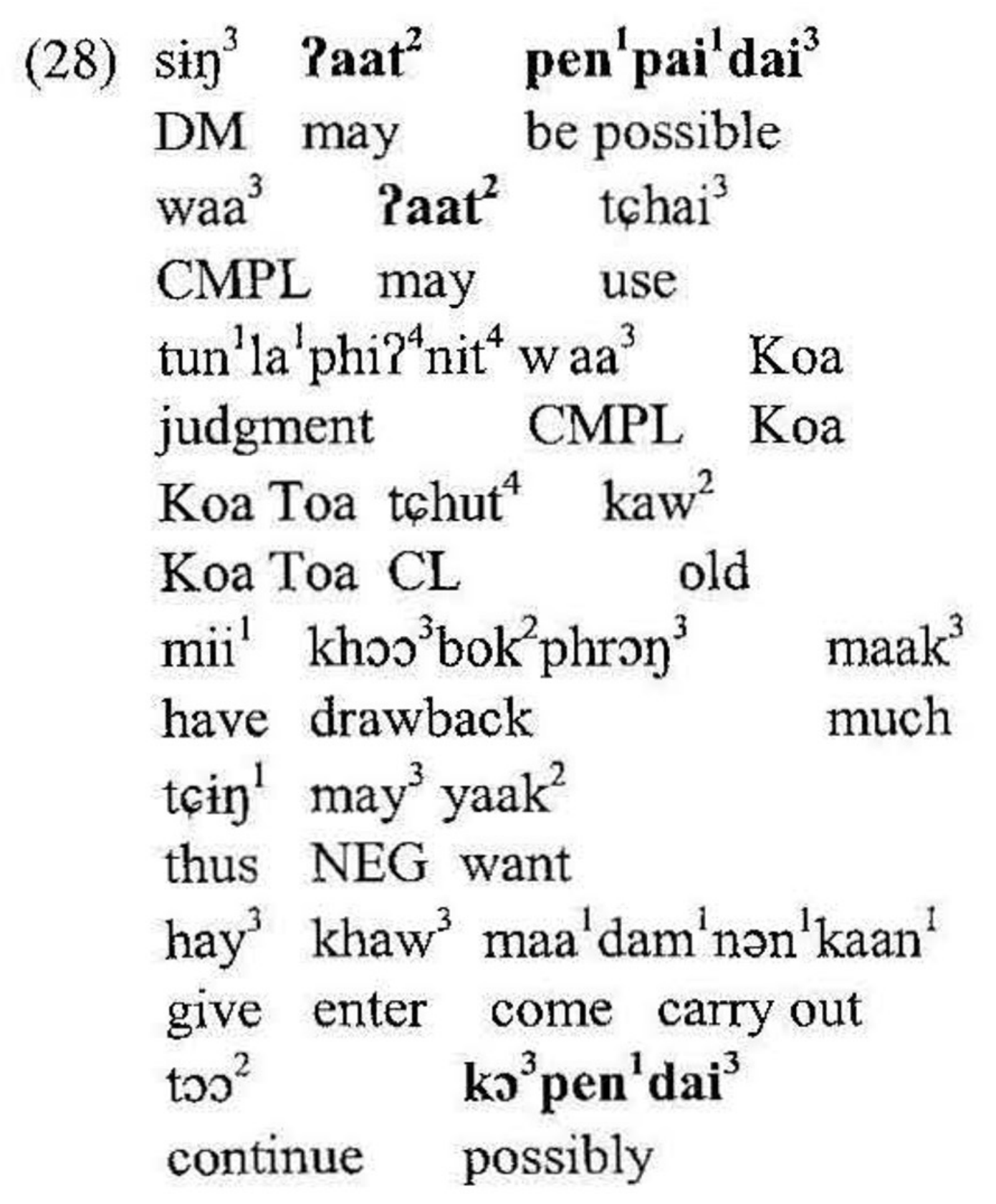

'It may be possible that they may use their authority in judging that the previous Koa Koa Toa committee (the Election
Commission of Thailand) had a lot of drawbacks such that they did not want them to continue the work, possibly.'

Sentence (28) is a complex sentence composed of four clauses. Its main clause, which is the first clause to the left, has the verb pen ${ }^{l}$ pal ${ }^{l} d a i^{3}$ 'be possible' which is an explicit means of indicating 'possibility'. The main clause is also marked with the epistemic modal Zaat $^{2}$ 'may', which occurs again in the next clause. The whole sentence indicates that the speaker does not commit to the truth of the proposition that the older Committee had a lot of drawbacks. The sentence is multiply qualified with markers of possibility, two of which are the same. Note that its meaning is not qualitatively different from a sentence with only one, or even none, epistemic modal, since the main verb already explicitly denotes that the proposition in the embedded clause is not the truth but just speculation. It can be concluded that this type of multiple use of epistemic markers is for emphasis. Notice that the sentence is a journalist's comment on the judgment of the election Committee which is a highly respected social organization. It is likely that the double marking of possibility for emphasis is a politeness strategy since making a comment is a positive-face threatening $\mathrm{act}^{7}$ such that the writer has to emphasize the speculation part.

To sum up, there are many other aspects of epistemic modality in Thai that need to be studied - syntactic, semantic, typological, cognitive and pragmatic. This study is an attempt to provide some basic analyses of this category. It is certainly also necessary

\footnotetext{
${ }^{7}$ P. Brown and S. Levinson (1987) Politeness: Some Universals in Language Usage. Cambridge: Cambridge University Press.
} 
to bring the basic findings from other related categories such as deontic modality and tense into the picture so that the system of epistemic modality can be more clearly explicated.

\section{Appendix: List of Abbreviation}

$\begin{array}{ll}\text { CMPL } & \text { Complementizer } \\ \text { CONT } & \text { Continuous marker } \\ \text { DM } & \text { Discourse marker } \\ \text { FP } & \text { Final particle } \\ \text { NEG } & \text { Negation } \\ \text { POSS } & \text { Possessive marker } \\ \text { PP } & \text { Polite particle } \\ \text { PROG } & \text { Progressive marker } \\ \text { RED } & \text { Reduplicative } \\ \text { 1sg } & \text { First person pronoun } \\ \text { 3sg } & \text { Third person singular } \\ & \text { pronoun }\end{array}$

\section{Bibliography}

Aijmer, K arin. 1997. I think - an English modal particle. In Toril Swan and Olaf Jansen Westvik (eds.), Modality in Germanic Languages: Historical and Comparative Perspectives. Berlin: Mouton de Gruyter.

Bhamoraput, Amara. 1972. Final Particles in Thai. Unpublished Master of Arts in Linguistics, Brown University.

Bandhumedha, Navavan. 1982. Wayakorn Thai. Bangkok: Rungreuangsarn.

Brown, Keith and Jim Miller (eds.) Concise Encyclopedia of Grammatical Categories. Amsterdam: Elsevier.

Brown, P. and S. Levinson 1987 Politeness: Some Universals in Language Usage. Cambridge: Cambridge University Press.
Bybee, Joan, Revere Perkins, and William Pagliuca. 1994. The Evolution of Grammar: Tense, Aspect, and Modality in the Languages of the World. Chicago: The University of Chicago Press.

Chung, Sandra and Timberlake, Alan. 1985. Tense, aspect, and mood. In Timothy Shopen (ed.), Language Typology and Syntactic Description Vol 3.: Grammatical Categories and the Lexicon, 203-258. Cambridge: Cambridge University Press.

Dalton-Puffer, Christiane and Nikolaus Ritt (eds.) 2000. Words:Structure, Meaning, Function. Berlin: Mouton de Gruyter.

Dellinger, David W. 1975. Thai modals. In Jimmy G. Harris and James R. Chamberlain (eds.) 89-99.

Enc, Murvet. 1996. Tense and Modality. In Shalom Lappin (ed.), The Handbook of Contemporary Semantic Theory, 345-358. Oxford: Blackwell.

Fortescue, Michael, Peter Harder and Lars Kristofersen (eds.) 1992. Layered Structure and Reference in a Functional Perspective: Papers from the Functional Grammar Conference in Copenhagen 1990. Amsterdam: John Benjamins.

Frawley, William. 1992. Linguistic Semantics. New Jersey: Lawrence Erlbaum.

Givon, T. 1982. Evidentiality and epistemic space. Studies in Language 6: 23-49. 
- 1984. Syntax : A FunctionalTypological Introduction Vol.1. Amsterdam : John Benjamins.

1990. Syntax : A FunctionalTypological Introduction Vol.2. Amsterdam : John Benjamins.

Hannay, Mike and Machtelt A. Bolkestein (eds.) 1998. Functional Grammar and Verbal Interaction, Amsterdam: John Benjamins.

Harris, Jimmy G. and James R. Chamberlain (eds.) 1975. Studies in Tai Linguistics. Bangkok: Central Institute of English Language.

Hickey, Raymond and Stanistaw Pupple (eds.) 1997. Language History and Linguistics Modelling Volume 2: Linguistic Modelling. Berlin: Mouton de Gruyter.

Jacobs, Joachim. 1991. On the semantics of modal particles. In Werner Abraham (ed.), Discourse Particles: Descriptive and Theoretical Investigation on the Logical, Syntactic and Pragmatic Properties of Discourse Particles in German, 141-162. Amsterdam: John Benjamins.

Johanson, Lars and Bo Utas (eds.) 2000. Evidentials: Turkic, Iranian and Neighbouring Languages. Berlin: Mouton de Gruyter.

Keller, Rudi. 1995. The epistemic weil. In Dieter Stein and Susan Wright (eds.), Subjectivity and Subjectivization: Linguistic Perspectives, 16-30. NY: Cambridge niversity Press.
Kullavanijaya, Pranee. 1968. A Study of Preverbs in Thai. Unpublished Master thesis, University of Hawaii.

Lappin, Shalom (ed.) 1996. The Handbook of Contemporary Semantic Theory. Oxford: Blackwell.

Lyons, John. 1977. Semantics. Cambridge: Cambridge University Press.

Nagle, Stephen J. 1997. What is double about double modals? In Raymond Hickey and Stanistaw Pupple (eds.) 1513-1526.

. 2000. On the semantics of the English double modals. In Christiane Dalton-Puffer and Nikolaus Ritt (eds.), 217-234.

Nida, Eugene A. 1949. Morphology: The Descriptive Analysis of Words. $\left(2^{\text {nd }}\right.$ ed.) Ann Arbor: The University of Michigan Press.

Noss, Richard B. 1964. Thai Reference Grammar. Washington D.C.: Foreign Service Institute.

Nuyts, Jan. 1992. Subjective vs. objective modality: What is the difference? In $\mathrm{M}$ ichael $\mathrm{F}$ ortescue, $\mathrm{P}$ eter $\mathrm{H}$ arder and Lars Kristofersen (eds.), 73-97.

- 2001. Epistemic Modality, Language, and Conceptualization: A Cognitive-Pragmatic Perspective. Amsterdam: John Benjamins.

Nuyts, Jan, A. M. Bolkestein, and C. Vet (eds.) 1990. Layers and Levels of Representations in Language Theory. Amsterdam: Benjamins. 
Palmer, F.R. 1986. Mood and Modality.

Cambridge:

University Press.

1999. Mood and Modality: Basic Principles. In Keith Brown and Jim Miller (eds.), Concise Encyclopedia of Grammatical Categories. Oxford: Elsevier Science.

Panupong, Vichin Chantavibulya. 1962. Inter-sentence relations in modern conversational Thai. Unpublished Ph.D. dissertation, School of Oriental and African Studies, University of London.

Panupong, Vichin. 1970. Inter-Sentence Relations in Modern Conversational Thai. Bangkok: The Siam Society.

Perry, John R. 2000. Epistemic verb forms in Persian of Iran, Afghanistan and Tajikistan. In Lars J ohanson and Bo Utas (eds.), Evidentials: Turkic, Iranian and Neighbouring Languages, 229-258. Berlin: Mouton de Gruyter.

Peyasantiwong, Patcharin. 1981. A Study of Final Particles in Conversational Thai. Ph.D. Dissertation, The University of Michigan.

Phatranawig, Phornthip. 1972. Modal expression in the Thai language. Unpublished Master thesis, Department of Thai, Chulalongkorn University.
Rangkupan, Suda. 2001. Linguistic characteristics of psychological perspective in Thai narrative discourse. $\mathrm{Ph} . \mathrm{D}$. dissertation, University at Buffalo, State University of New York.

Shimpaiboon, Valee. 1966. Thai auxiliaries. Unpublished Master thesis, Department of Secondary School Education, Chulalongkorn University.

Sindhvananda, Kanchana. 1970. The verb in modern Thai. Ph.D. dissertation, Georgetown University.

Sookgasem, Prapa. 1990. Morphology, syntax and semantics of auxiliaries in Thai. Ph. D. dissertation, University of Arizona.

Sriphen, Salee. 1982. The Thai verb phrase. $\mathrm{Ph} . \mathrm{D}$. dissertation, University of Michigan.

Steele, Susan. 1975. Is it possible? Working Papers on Language Universals, No. $18,35-58$.

Swan, Toril and Olaf Jansen Westvik (eds.) 1997. Modality in Germanic Languages: Historical and Comparative Perspectives. Berlin: Mouton de Gruyter.

Sweetser, Eve. 1990. From Etymology to Pragmatics: The Mind-as-Body Metaphor in Semantic Structure and Semantic Change. Cambridge: Cambridge University Press.

Upakitsilpasaan, Phraya. 1937, 1968. Lak Phaasaa Thai. Bangkok: Thaiwatthanapanich. 
Usoniene, Aurelia. 2001. On the modality of the English verbs of seeming. In Johan van der Auwera and Patrick Dendale (eds.), 185-206.

Van Valin, Robert D., Jr. and Randy J. LaPolla. 1997. Syntax: Structure, meaning and function. Cambridge: Cambridge University Press.

van der Auwera, Johan and Patrick Dendale (eds.) 2001. Modal Verbs in Germanic and Romance Languages. Amsterdam: John Benjamins.

Vet, Co. 1998. Epistemic possibility in the layered structure of the utterance. In Mike Hannay and Machtelt A. Bolkestein (eds.) 149-165. 